\title{
RANKL expression is differentially modulated by TLR2 and TLR4 signaling in fibroblasts and osteoblasts
}

Fabio Renato Manzolli Leite ${ }^{1,2}$, Sabrina Garcia de Aquino ${ }^{1}$, Morgana Rodrigues Guimarães ${ }^{1 *}$, Joni Augusto Cirelli ${ }^{1}$ and Carlos Rossa Junior ${ }^{1}$

*Correspondence: morganaguimaraes@yahoo.com.br

\section{CrossMark}

- Click for updates

'Department of Diagnosis and Surgery, School of Dentistry at Araraquara, Univ. Estadual Paulista (UNESP), Araraquara, Sao Paulo, Brazil.

${ }^{2}$ School of Dentistry, Federal University at Pelotas (UFPel), Pelotas, RS, Brazil.

\begin{abstract}
Resident, non-immune cells express various pattern-recognition receptors and produce inflammatory cytokines in response to microbial antigens, during the innate immune response. Alveolar bone resorption is the hallmark of destructive periodontitis and it is caused by the host response to bacteria and their mediators present on the biofilm. The balance between the expression levels of receptor activator of nuclear factorkappa B ligand (RANKL) and osteoprotegerin (OPG) is pivotal for osteoclast differentiation and activity and has been implicated in the progression of bone loss in periodontitis. To assess the contribution of resident cells to the bone resorption mediated by innate immune signaling, we stimulated fibroblasts and osteoblastic cells with LPS from. Escherichia coli (TLR4 agonist), Porphyromonas gingivalis (TLR2 and -4 agonist), and interleukin-1 beta (as a control for cytokine signaling through Toll/IL-1 receptor domain) in time-response experiments. Expression of RANKL and OPG mRNA was studied by RT-PCR, whereas the production of RANKL protein and the activation of p38 MAPK and NF-kB signaling pathways were analyzed by western blot. We used biochemical inhibitors to assess the relative contribution of p38 MAPK and NF-kB signaling to the expression of RANKL and OPG induced by TLR2, -4 and IL1 $\beta$ in these cells. Both p38 MAPK and NF$\mathrm{kB}$ pathways were activated by these stimuli in fibroblasts and osteoblasts, but the kinetics of this activation varied in each cell type and with the nature of the stimulation. E. coli LPS was a stronger inducer of RANKL mRNA in fibroblasts, whereas LPS from $P$. gingivalis downregulated RANKL mRNA in periodontal ligament cells but increased its expression in osteoblasts. IL-1 $\beta$ induced RANKL in both cell types and without a marked effect on OPG expression. p38 MAPK was more relevant than NF-kB for the expression of RANKL and OPG in these cell types.
\end{abstract}

Keywords: Lipopolysaccharide, porphyromonas gingivalis, cell signaling, RANKL, OPG

\section{Introduction}

The essential role of RANKL/RANK/OPG axis in osteoclast differentiation/activation in inflammatory bone diseases, including periodontal disease is widely acknowledged [1]. In the inflamed periodontal microenvironment, various cell types are capable of expressing RANKL, including periodontal ligament fibroblasts, leading to tissue destruction through activation of RANK on pre-osteoclasts [2]. In fact, increased expression of RANKL associated with reduced expression of OPG was observed in both animal models [3] and human periodontallydiseased sites [1]. Specifically in periodontal disease, bacterial lipopolysaccharide (LPS) of Gram-negative microorganisms has shown both in vitro [4] and in vivo [5] an important role in damage process by inducing the expression of various inflammatory mediators including: IL-1, IL-6 and IL-8 [6], which can indirectly promote RANKL expression which ultimately result in alveolar bone loss that was initiated by Toll-like receptors (TLRs) signaling [7]. LPS from Gram-negative bacteria of the subgingival biofilm associated with periodontal disease activate both TLR2 and $-4[8,9]$. We have previously shown that TLR4 stimulation in periodontal ligament fibroblasts result in increased RANKL expression, which is at least partially dependent on p38 MAPK signaling [10]. In the periodontal tissues, gingival fibroblasts (GF) [11], periodontal ligament fibroblasts (PDL) [12] and osteoblasts [13] were shown to express TLR2 and TLR4 constitutively, which indicates that these cells are responsive to bacterial LPS [6]. In this context, these cell types that are classically thought of as contributing to periodontal tissue homeostasis [14] can also 
Leite et al. Immunology Innovation 2014,

participate in bone resorption during microbial aggression through secretion of many immunoregulatory cytokines [15]. Some of the cytokines produced by these resident cell types, such as IL-6 [16], may not only act synergistically with the pathogen-associated molecular patterns in the activation of dendritic cells and modulation of the adaptive immune response, but can also have direct effects on of tissue degradation and bone resorption. Other inflammatory mediators and cytokines produced by the resident cell types in response to TLR signaling may have primarily direct effects on the modulation of tissue degradation, including matrix metalloproteases, PGE2 and RANKL. Thus, the cytokine network associated with diseased periodontal tissues is highly complex, and it is currently thought that the cytokine profile ultimately determines disease activity [17]. This cytokine profile is the consequence of the activation of different signaling pathways by a multitude of external signals present in the periodontal microenvironment, resulting in a signaling network that modulates cytokine production. Considering the infectious nature of periodontal disease and the crucial role of bacterial LPS as a ubiquitous and chronically present microbial stimulus activating TLR2 and -4, we studied LPS-induced activation of signaling pathways that are especially relevant for expression of inflammatory genes. LPS stimulation may have a positive role in the modulation of osteoclastogenesis by inducing RANKL and/or inhibiting OPG expression or a negative role by reducing the expression of RANK or M-CSF receptor on osteoclast precursor cells [18]. In human gingival fibroblasts, LPS had a bone-protective effect by inducing the production of OPG [19]. In this study we present data on the differential regulation of RANKL and OPG gene expression after activation of TLR2, -4 and IL1R in fibroblasts and osteoblasts, providing insight into the relative contribution of p38 MAPK and NF-kB signaling to the expression of these genes in each cell type.

\section{Material and methods \\ Cells and materials}

Mouse periodontal ligament fibroblasts (mPDL), immortalized with simian vírus 40 large $T$ antigen, were originally obtained from Dr Martha J. Somerman (NIH/NIDCR, Bethesda, MD, USA). These cells were previously characterized for the expression of genes normally expressed by primary periodontal ligament cells, including bone sialoprotein, osteopontin, osteocalcin and type I collagen. Osteoblastic rat osteosarcoma cells ROS 17/2.8 (ROS) were obtained from Dr. Laurie McCauley (University of Michigan, Ann Arbor, MI, USA). Osteoblast phenotypic mRNAs, including bone sialoprotein and osteocalcin, were routinely assayed to verify osteoblastic phenotype expression in these cells. Unless noted otherwise, all tissue culture reagents were obtained from Invitrogen/Life Technologies (Carlsbad, CA, USA). Lipopolysaccharide from Escherichia coli (serotype O55:B5) was purchased from Sigma-Aldrich (St Louis, MO, USA) and Porphyromonas gingivalis lipopolysaccharide was purchased from Invivogen (San Diego, CA, USA). Biochemical inhibitors of p38 MAPK (SB203580) and NF-kB (Bay-110782) were purchased from Sigma-Aldrich (St Louis, MO, USA). Both E. coli and $P$. gingivalis lipopolysaccharide were diluted in RNAse-free water to $5 \mathrm{mg} / \mathrm{mL}$. Recombinant human Interleukin- $1 \mathrm{~b}$ protein was from R\&D systems (Minneapolis, MN, USA) and was diluted in PBS containing $0.1 \% \mathrm{BSA}$. All primer pairs were purchased from Invitrogen/Life Technologies (Carlsbad, CA, USA). Mouse RANKL monoclonal antibody was obtained from Imgenex (San Diego, California, USA). Phosphorylated p38 monoclonal antibody was from Cell Signaling (Danvers, MA, USA), whereas the monoclonal antibody for glyceraldehyde-3-phosphate dehydrogenase (GAPDH) and the polyclonal antibody for phosphorylated p50 were from Santa Cruz Biotechnology (Santa Cruz, CA, USA).

\section{Stimulation}

Both mPDL and Ros17/2.8 cells were grown in Dulbecco's Modified Eagle's Medium supplemented with $100 \mathrm{IU} / \mathrm{mL}$ of penicillin, $100 \mathrm{ug} / \mathrm{mL}$ of streptomycin and $10 \%$ heat-inactivated fetal bovine serum, and maintained in a humidified atmosphere at $37^{\circ} \mathrm{C}$ and $5 \% \mathrm{CO}_{2}$. After plating, the cells were left to attach overnight in complete growth medium, routinely de-induced in medium containing $0.3 \%$ FBS for $6 \mathrm{~h}$ and then stimulated with the indicated concentrations of the agonists and for the indicated periods. In the experiments assessing the role of p38 MAPK and NF-kB on RANKL and OPG gene expression, 10 uM of either SB203580 or Bay-110782 were added to the cultures 30 min before the stimulation with the LPSs or IL-1b. All experiments were performed in duplicate and repeated in an independent manner a minimum of three times.

\section{Semi-quantitative RT-PCR}

Total RNA was isolated from cells using Trizol (Invitrogen) according to the manufacturer's instructions. The quantity and purity of total RNA were determined on a Biomate 3 (Thermo Electron Corporation) spectrophotometer. Complementary DNA was synthesized by reverse transcription of $500 \mathrm{ng}$ of total RNA using $2.5 \mu \mathrm{M}$ Oligo (dT) 12-18 primers and $1.25 \mathrm{U} / \mathrm{uL}$ Moloney murine leukemia virus reverse transcriptase in the presence of $3 \mathrm{mM} \mathrm{MgCl} 2,2 \mathrm{mM}$ dNTPs and $0.8 \mathrm{U} / \mu \mathrm{L}$ of RNAse inhibitor, according to the manufacturer's protocol (Improm II-Promega). The PCR reaction was performed in a MyCycler (Bio-Rad) thermocycler using $2 \mathrm{uL}$ of the $\mathrm{RT}$ reaction product on a $25 \mathrm{uL}$ total volume PCR reaction mix (GoTaq Flexi, Promega). It was used $100 \mathrm{pmol} / \mathrm{ul}$ of each gene's primers $(50 \mathrm{pmol} / \mathrm{ul}$ of sense and antisense primers) for RANKL, OPG and GAPDH genes yielding products of $467,140,503$ and $418 \mathrm{bp}$ for RANKL (mouse-mPDL), RANKL (rat-ROS) OPG and GAPDH, respectively. The primer pair used for RANKL-mouse-(accession no.: NM011613) was: sense 5'-CAGCACTCACTGCTTTTATAGAATCC3'; antisense 5'-AGCTGAAGATAGTCTGTAGGTACGC-3'; for RANKL-rat-(accession no.: NM057149) was: sense 5'-TCGGGTTCCCATAAAGTCAG-3', antisense 5'-CTGAAGCAAATGTTGGCGTA, for osteoprotegerin (accession no: 
Leite et al. Immunology Innovation 2014,

NM008764) was: sense 5'-TGTAGAGAGGATAAACGG - 3'; antisense 5'-CTAGTTATATGCAGCTTAT-3'; and for GAPDH (accession no.: BC083065) was: sense 5'-CACCATGGAGAAGGCCGGGG-3'; antisense 5'-GACGGA-CACATTGGGGTAG-3'. Optimyzed cycling conditions used for RANKL (from mouse) and OPG were: initial denaturation at $95^{\circ} \mathrm{C}$ for $2 \mathrm{~min}$ and 30 cycles $(35$ cycles for OPG) of: $95^{\circ} \mathrm{C}$ for $1 \mathrm{~min}, 56^{\circ} \mathrm{C}$ for $1 \mathrm{~min}, 72^{\circ} \mathrm{C}$ for $2 \mathrm{~min}$, and a final extension step at $72^{\circ} \mathrm{C}$ for $7 \mathrm{~min}$ in the presence of $2.5 \mathrm{mM} \mathrm{MgCl}$, whereas for RANKL (from rat) the cycling conditions were as follows: initial denaturation at $95^{\circ} \mathrm{C}$ for $2 \mathrm{~min}$ and $40 / 36 \mathrm{cycles}$ of: $95^{\circ} \mathrm{C}$ for $15 \mathrm{sec}, 58^{\circ} \mathrm{C}$ for $30 \mathrm{sec}$, $72^{\circ} \mathrm{C}$ for $30 \mathrm{sec}$ and a final extension step at $72^{\circ} \mathrm{C}$ for $7 \mathrm{~min}$ in the presence of $2.5 \mathrm{mM} \mathrm{MgCl}$ 2. For GAPDH, RT thermocycler conditions were as follows: initial denaturation at $95^{\circ} \mathrm{C}$ for $2 \mathrm{~min}$ and $25 \mathrm{cycles}$ of: $95^{\circ} \mathrm{C}$ for $1 \mathrm{~min}, 52^{\circ} \mathrm{C}$ for $1 \mathrm{~min}, 72^{\circ} \mathrm{C}$ for $1 \mathrm{~min}$ and a final extension step at $72^{\circ} \mathrm{C}$ for $10 \mathrm{~min}$ in the presence of $1.5 \mathrm{mM} \mathrm{MgCl}$. The $\mathrm{PCR}$ products were resolved by electrophoresis on $1.5 \%(\mathrm{w} / \mathrm{v})$ agarose gels containing ethidium bromide $(0.5 \mu \mathrm{g} / \mathrm{mL})$. The amplified DNA bands were analyzed densitometrically after digital imaging capture (Image Quant 100-GE Healthcare), using Image J 1.45s software (National Institute of Health, USA-http://imagej.nih.gov/ij). The density of the bands corresponding to RANKL and OPG mRNA in each sample was normalized to the amount of the housekeeping gene GAPDH and expressed as fold change over unstimulated control.

\section{Western blot}

A total of $10^{5}$ mouse periodontal ligament cells (as well as of ROS osteoblastic cells) were grown for $24 \mathrm{~h}$ in each well of six-well plates, de-induced by incubation for $12 \mathrm{~h}$ in culture medium containing $0.3 \%$ fetal bovine serum and stimulated with either E. coli LPS (100 ng/ $\mathrm{mL}$ or $1 \mathrm{ug} / \mathrm{mL})$, P. gingivalis LPS (1ug/mL or $10 \mathrm{ug} / \mathrm{mL})$ or IL-1b (1ng/mL or $10 \mathrm{ng} / \mathrm{mL})$ for 10,20 , 60 and $120 \mathrm{~min}$ for assessing activation of NF-KB and p38 MAPK, and also for $24 \mathrm{~h}$ and $48 \mathrm{~h}$ for RANKL protein expression. Whole cell lysates were prepared by scraping the cells of each well of six-well plates with 100 ul of sodium dodecyl sulfate sample buffer (62.5 mM Tris HCl buffer, pH 6.8, 10\% glycerol, 50 mM dithiothreitol, $2 \%$ sodium dodecyl sulfate, $0.01 \%$ bromophenol blue) on ice, followed by centrifugation at $9,000 \mathrm{RPM}$ at $4^{\circ} \mathrm{C}$ for 5 minutes. $40 \mathrm{uL}$ of this content was heat-denatured at $95^{\circ} \mathrm{C}$ for 5 minutes and separated on $10 \%$ Tris- $\mathrm{Cl}$ polyacrylamide gels run at $100 \mathrm{~V}$ for $90 \mathrm{~min}$ and subsequently electro-transferred to $0.2 \mu \mathrm{m}$ nitrocellulose membranes ( $300 \mathrm{~mA}$ constant current for 60 minutes). The membranes were blocked (Tris-buffered saline with $5 \%$ nonfat dry milk, $0.1 \%$ Tween-20) for 1 hour at room temperature and then incubated overnight at $4{ }^{\circ} \mathrm{C}$ with primary antibodies. The presence of the primary antibodies was detected on radiographic film by using HRP-conjugated secondary antibodies and a chemiluminescence system (LumiGlo, Cell Signaling). The membranes were stripped off both primary and secondary antibodies by 10 -minute washing in $\mathrm{dH} 2 \mathrm{O}(2 \mathrm{x})$ followed by incubation in stripping buffer (100 mM 2-mercaptoethanol, 2\% SDS, $62.5 \mathrm{mM}$ Tris-Cl, $\mathrm{pH}$ 6.7) for 10 minutes at room temperature and a final 10-minute wash in Tris-buffered saline containing $0.1 \%$ Tween-20. After stripping, the membranes were blocked as described previously and incubated with antibody against Glyceraldehyde 3-phosphate dehydrogenase (GAPDH) to verify equal loading of the wells. Digitalized images of the radiographic films were obtained in a gel documentation system (ImageQuant 100, GE Lifesciences) and densitometric measurements were obtained using ImageJ 1.45s software (NIH, Bethesda, MD, USA-http://imagej.nih. gov/ij).

\section{Statistical analysis}

Pairwise comparisons between experimental groups were performed using the t-test with Welch's correction for unequal variances. Comparison between fold changes on mRNA expression between lipopolysaccharide-stimulated and untreated cells was performed with the one-sample t-test. The significance level was set to $5 \%$ and all calculations were performed using PRISM 4 software (GraphPad, Inc., San Diego, CA, USA).

\section{Results \\ Differential activation of NF- $\mathrm{KB}$ and p38 MAPK by TLR2, -4 and IL1R}

TLR4, TLR2 and IL1R signaling was induced by stimulating both osteoblastic and fibroblastic cells with LPS from E. coli, LPS from $P$. gingivalis and with rhIL-1 $\beta$, respectively. In periodontal ligament fibroblasts, activation of p38 MAPK was biphasic using either LPS or IL-1 $\beta$. However, TLR signaling resulted in delayed activation of p38 in comparison to IL-1R signaling (10 and 60 minutes for IL-1R versus 20 and 120 minutes for TLR signaling; Figure 1A). Interestingly, activation of p38 MAPK was more intense with the lower concentration of LPS (100 $\mathrm{ng} / \mathrm{mL})$, whereas the higher concentration of LPS $(1 \mu \mathrm{g} / \mathrm{mL})$ resulted in a time-dependent activation with less evident peaks. In osteoblastic cells, TLR2 signaling was a more potent activator of p38 and NF-kB than TLR4 signaling. Stimulation of IL-1R in these cells was of intermediary potency in comparison to TLR2 and TLR4, but similarly to the fibroblasts resulted in more rapid and transitory activation, in particular of NF-kB (Figure 1B).

\section{RANKL and OPG mRNA expression}

Activation of TLR4 signaling in periodontal ligament fibroblasts resulted in a concentration-dependent increase on RANKL mRNA expression in later experimental periods (Figure 2A), whereas OPG mRNA levels were not affected. In contrast, TLR2 signaling significantly inhibited RANKL mRNA expression in these cells (Figure 2B), returning to basal/constitutive levels only 24 hours after stimulation with $P$. gingivalis LPS. There was also a trend to decrease OPG mRNA expression with activation of TLR2 signaling, but this inhibition was not as marked as for RANKL. In IL-1 $\beta$-stimulated periodontal ligament fibroblasts 
Leite et al. Immunology Innovation 2014,

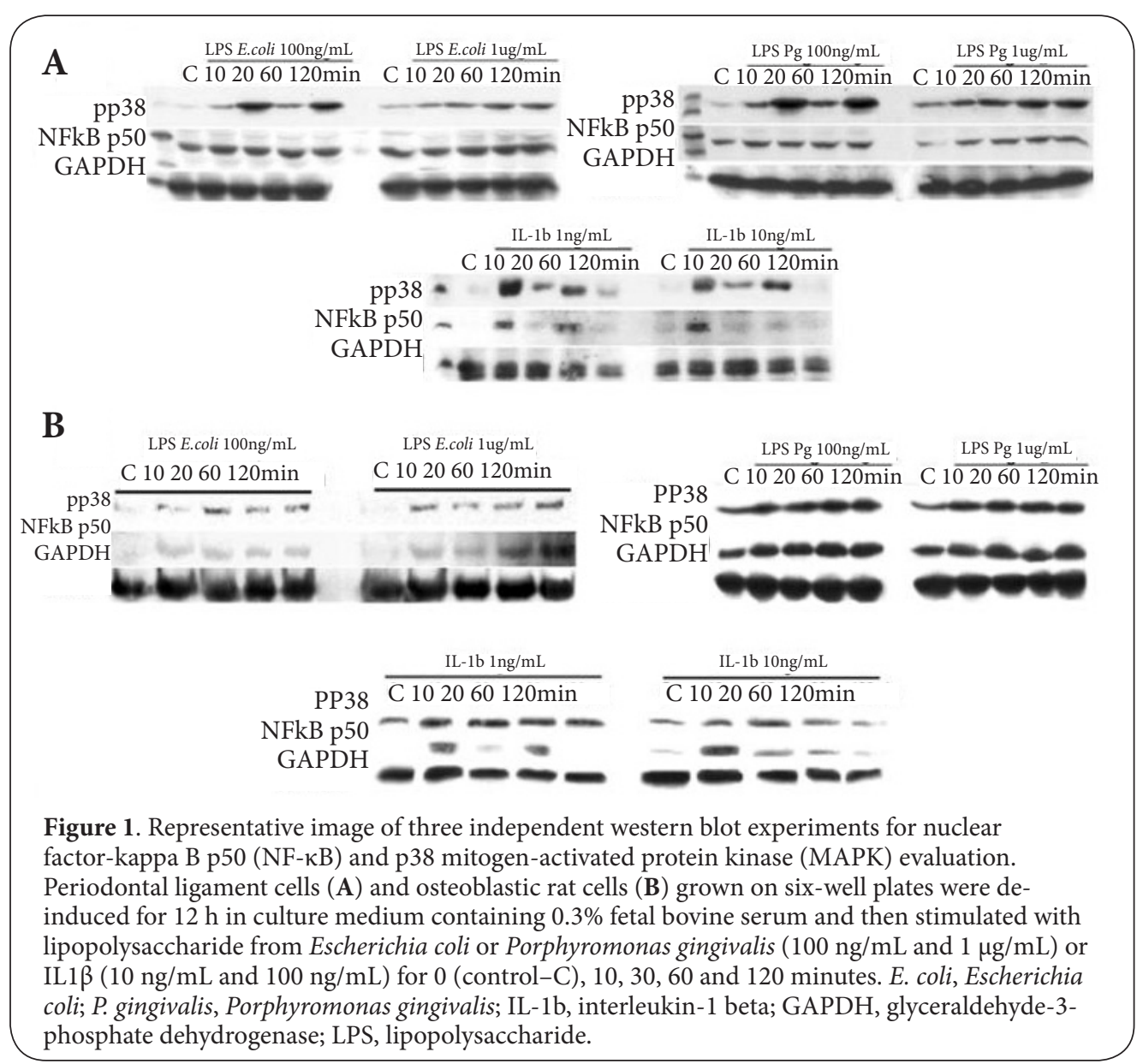

a more rapid induction of RANKL mRNA occurred with both IL-1 $\beta$ concentrations (Figure $2 \mathrm{C}$ ), followed by a decrease in later experimental periods ( 18 and $24 \mathrm{~h}$ ). A discrete and rapid increase of OPG mRNA expression was also observed in earlier experimental periods, particularly with the higher concentration of IL-1 $\beta$.

In osteoblastic cells, TLR4 stimulation by E. coli LPS (Figure 3A) also resulted in a greater induction of RANKL $m R N A$, which was directly proportional to the concentration of LPS. In contrast to the periodontal ligament fibroblasts, induction of RANKL occurred at early experimental periods, returning to the basal/ constitutive levels 24 hours after stimulation. Interestingly, in osteoblasts the induction of OPG mRNA was inversely proportional to the concentration of E. coli LPS. Contrary to the inhibitory effect in periodontal ligament fibroblasts, activation of TLR2 by $P$. gingivalis LPS in osteoblastic cells increased RANKL mRNA expression, with approximately the same potency as IL-1b (Figure 3B). OPG mRNA levels fluctuated over time, but there was a trend of increased expression, especially after stimulation with E. coli LPS and IL-1 $\beta$.

\section{RANKL protein production}

Regulation of RANKL at the protein level supported E. coli LPS as an inducer of RANKL, and this expression was sustained for $48 \mathrm{~h}$ after the stimulation. Consistently with the inhibitory effect on mRNA expression, P. gingivalis LPS failed to induce RANKL protein at $24 \mathrm{~h}$; however, a slight but significant increase was observed after $48 \mathrm{~h}$. In contrast to the regulation of mRNA, IL-1 $\beta$ was a more potent inducer of RANKL protein expression than E. coli LPS; however IL-1b-mediated induction of RANKL protein was observed only at $24 \mathrm{~h}$, with a return to the basal levels of expression at 48 hours (Figure 4A). In another contrast with the periodontal ligament fibroblasts, E. coli LPS was a more potent inducer of RANKL at the protein level in osteoblasts, and this induction was sustained for $48 \mathrm{~h}$ after the stimulation. IL-1b and $P$. gingivalis LPS resulted in slight, albeit significant, increases on RANKL protein expression in osteoblastic cells (Figure 4B).

\section{Utilization of p38 MAPK and NF-kB pathways by fibroblasts and osteoblasts}

Expression of RANKL mRNA induced by TLR2, -4 and IL1R was dependent primarily on p38 MAPK in fibroblasts as indicated by the greater relative decreases on RANKL mRNA expression when the stimulations were performed with pre-treatment with 10 uM SB203580. Inhibiting NF-kB with 10 uM of Bay 11- 


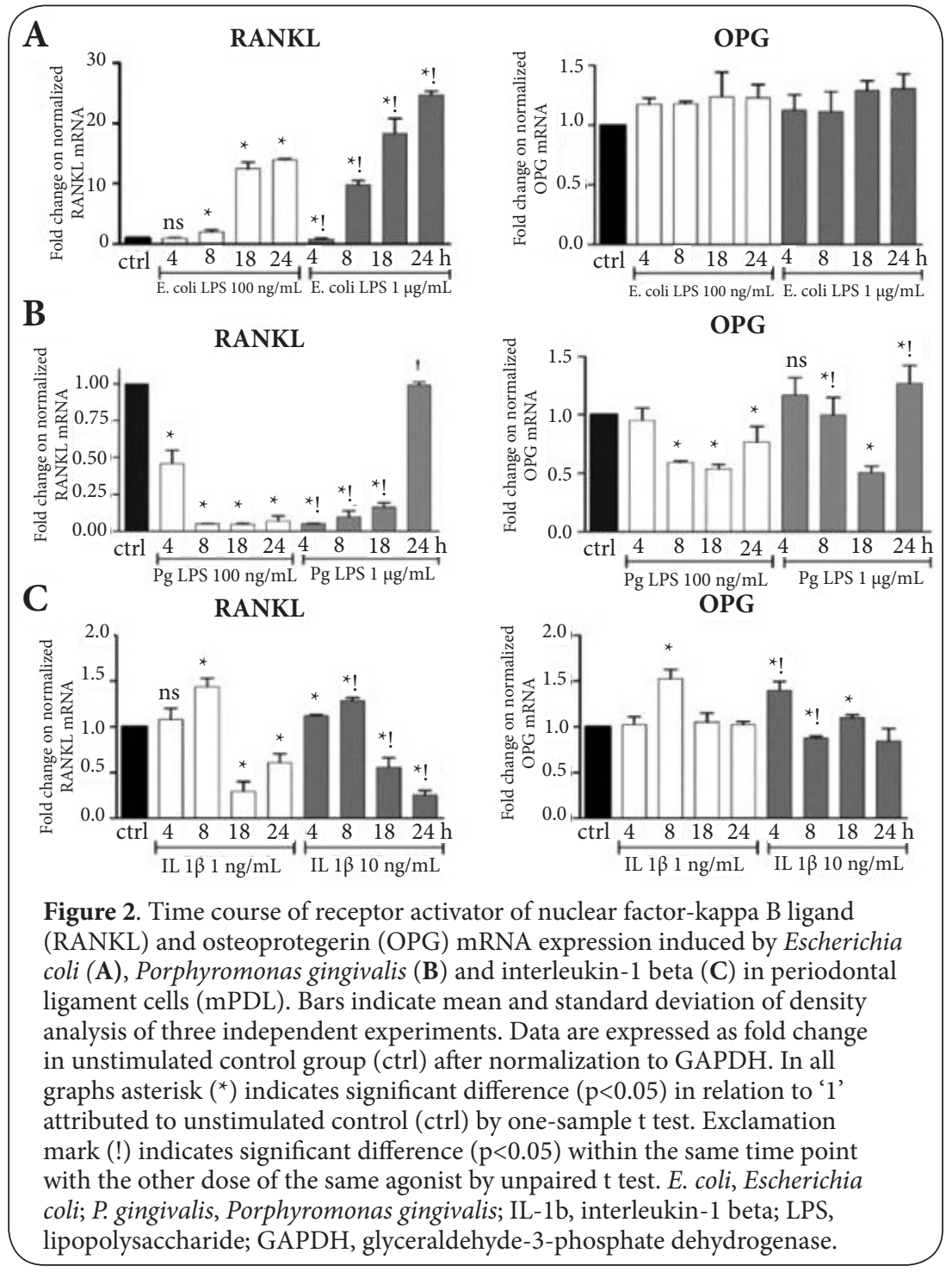

0782 attenuated RANKL expression after stimulation of TLR4 and IL1R, but not TLR2 in fibroblasts. On the other hand, in osteoblasts inhibition of p38 MAPK signaling reduced RANKL expression after stimulation of TLR2 and-4, but not after IL1R activation. Inhibition of NF-kB reduced TLR4-induced RANKL expression, but it was associated with an increase on RANKL expression induced by TLR2 activation in these cells.

The discrete regulation of OPG mRNA was partly dependent on both p38 MAPK and NF-kB activation in both fibroblasts and osteoblasts and for all stimuli, except for the slight increase associated with the activation of TLR2 in osteoblasts that was independent of NF-kB (Figures 5A and 5B).

\section{Discussion}

In the periodontal disease microenvironment, the ubiquitous presence of various MAMPs and the widespread expression of PRRs by immune and non-immune cell types suggest that innate immune signaling in 'non-professional'/resident cell types play a role modulating the host response. Importantly, cell type and differentiation state can influence both the expression of PRR, and also the signaling pathways activated by the same MAMPs [20].

Our research group has previously shown that p38 MAPK and its upstream activators MKK3 and MKK6 play an important role on lipopolysaccharide-induced RANKL expression by periodontal ligament cells [10], and in this study, we report that signaling through TLR2, TLR4 and IL1R results in differential modulation of RANKL gene expression. Moreover, a biphasic activation of p38 MAPK with delayed kinetics is associated with TLR signaling. The delayed activation of p38 MAPK upon TLR4 signaling is associated with a delayed induction of RANKL mRNA in comparison to IL1R signaling. Moreover, TLR4-induced expression of RANKL mRNA in fibroblasts was primarily dependent on $\mathrm{p} 38$ MAPK activation. A previous study 


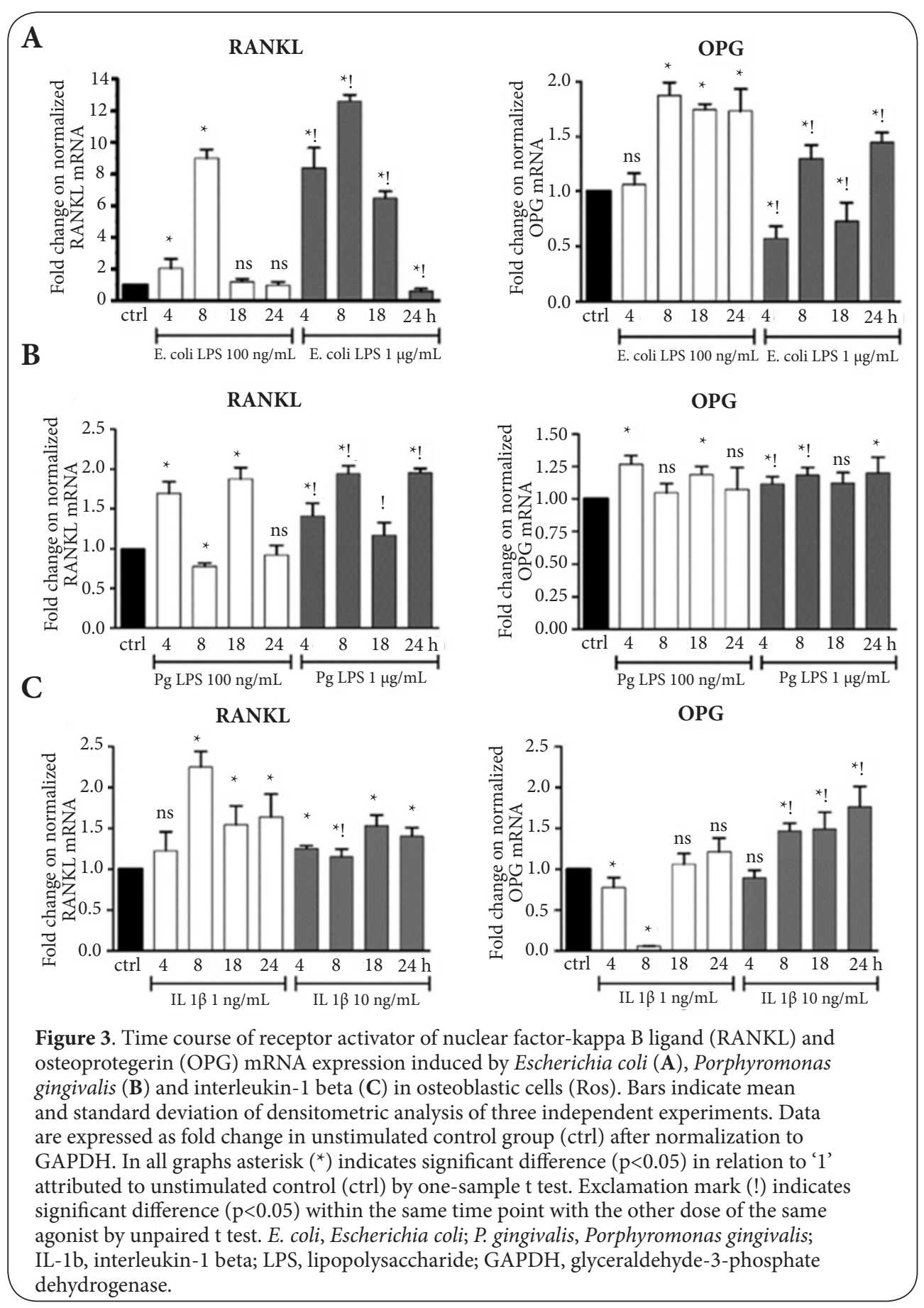

suggested that RANKL and OPG expression in periodontal ligament cells was indirectly induced by the production of IL-1 $\beta$ and TNF- $\alpha$ hours after LPS stimulation [21]. Our data show that induction of RANKL mRNA occurred mostly 8 hours or more subsequent to stimulation, so we cannot rule out a possible autocrine/paracrine influence by early-response genes in our results. Consistent with this possibility, when stimulated with IL-1 $\beta$ both periodontal ligament fibroblasts and osteoblasts showed a more rapid increase of RANKL
mRNA. However, at the protein level these different agonists showed varying potencies in each cell type. E. coli LPS potently induced RANKL protein in osteoblastic cells, whereas IL-1b was a stronger inducer in periodontal ligament fibroblasts. It is tempting to speculate on potentially different roles for these cell types in periodontal disease based on their differential response to the same agonists: osteoblasts were more responsive to TLR signaling and periodontal ligament cells more sensitive to inflammatory mediators, e.g., IL-1, that 


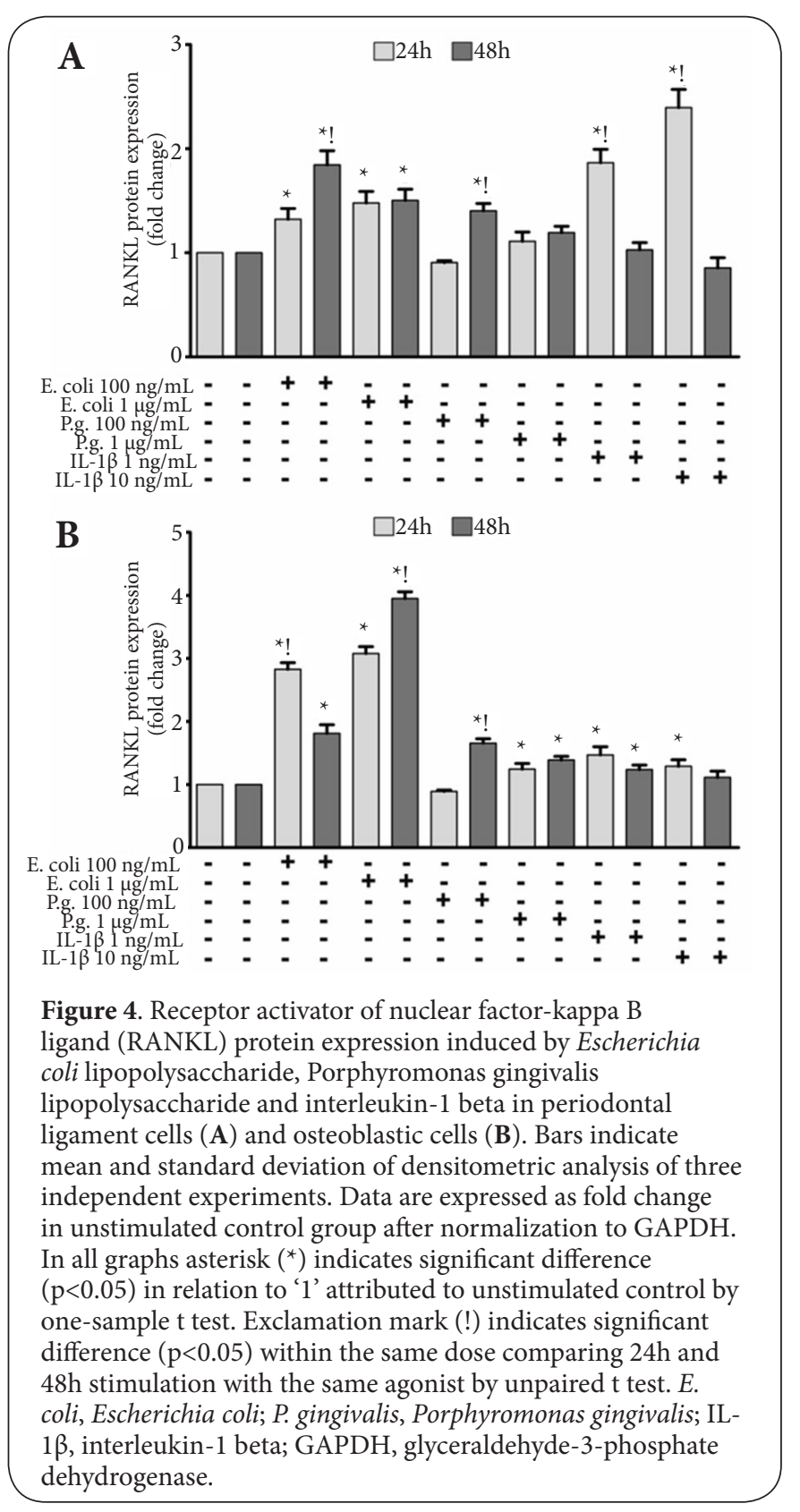

may be produced in response to the initial bacterial challenge or in situation associated with mechanical stress such as orthodontic movement or traumatic occlusion. Activation of nuclear factor-kappa B (NF-kB) followed a similar pattern regardless of cell type, suggesting it is receptor-dependent with distinct results for TLR or IL1R stimulation. In both periodontal ligament fibroblasts and osteoblastic cells only IL1R signaling resulted in biphasic activation of NF-kB (especially with the lower concentration of IL-1b), whereas TLR2 and TLR4 signaling was associated with a more sustained activation over time. IL-1 $\beta$ signaling through IL1R may also follow an alternative pathway that is associated with the second peak of activation of NF-kB representing delayed NF-KB activation through TAK1,
A
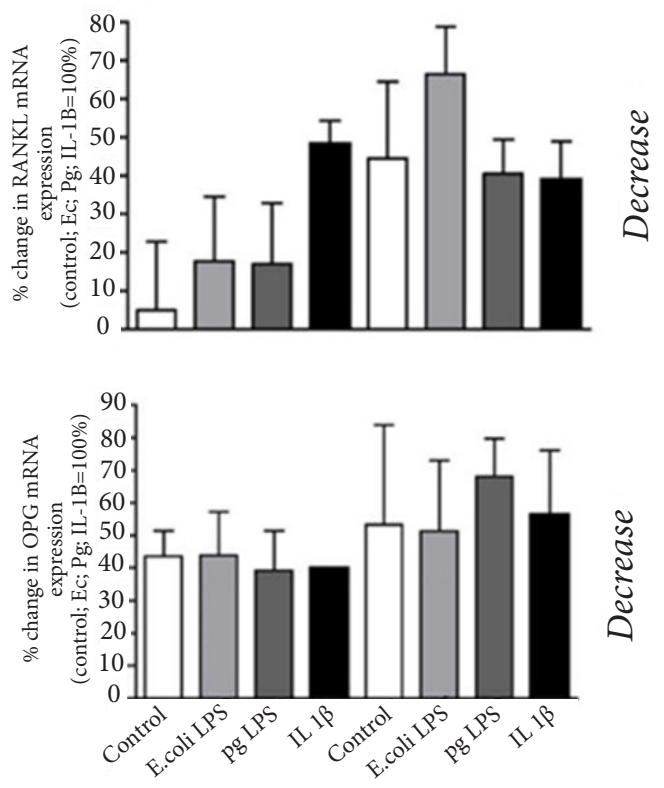

B
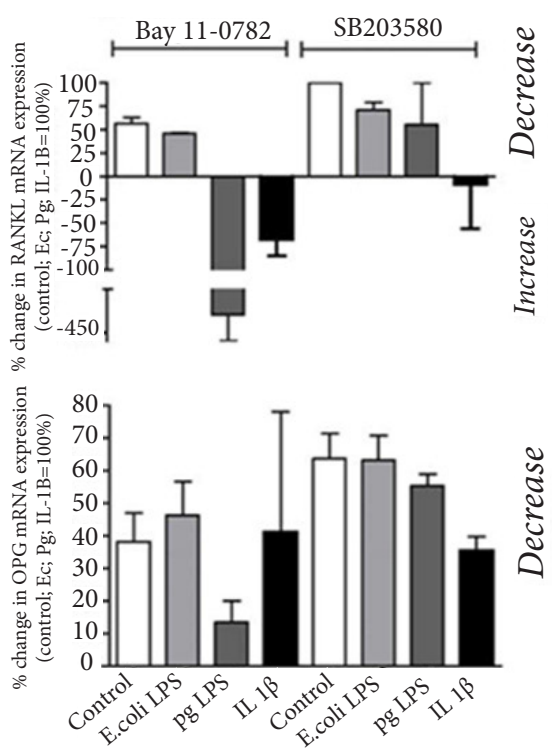

Figure 5. Relevance of $\mathrm{p} 38 \mathrm{MAPK}$ and NF-kB for expression of RANKL and OPG mRNA upon activation of TLR2, TLR4 and IL1R in fibroblasts (A) and osteoblasts (B). Bars indicate mean and standard deviation of densitometric analysis of three independent experiments. Data are expressed as percent change (decrease) of normalized target gene expression when the stimulations were conducted in the presence of pretreatment with specific inhibitors for p38 MAPK (SB203580) or NF-kB (Bay 11-0782). In all graphs asterisk $\left(^{*}\right)$ indicates significant difference $(\mathrm{p}<0.05)$ in relation to ' 1 ' attributed to unstimulated control by one-sample $t$ test. Exclamation mark (!) indicates significant difference $(\mathrm{p}<0.05)$ within the same dose comparing $24 \mathrm{~h}$ and $48 \mathrm{~h}$ stimulation with the same agonist by unpaired t test. E. coli, Escherichia coli; P. gingivalis, Porphyromonas gingivalis; IL- $1 \beta$, interleukin-1 beta; GAPDH, glyceraldehyde-3-phosphate dehydrogenase. 
Leite et al. Immunology Innovation 2014,

http://www.hoajonline.com/journals/pdf/2053-213X-2-1.pdf

doi: 10.7243/2053-213X-2-1

which, together with TRAF6, is also an upstream activator of MAPKinases [22]. Interestingly, regulation of RANKL and OPG mRNA induced by TLR2, -4 and IL1R was primarily dependent on p38 MAPK in both fibroblasts and osteoblasts; with NF-kB activation, a major downstream signaling effector of TLRs and IL1R, having a more prominent role on IL1b-induced RANKL mRNA expression by fibroblasts.

The inhibitory effect of on RANKL mRNA upon stimulation with $P$. gingivalis LPS is both unexpected and intriguing. It is possible that this effect may represent a cell-type specific effect, as this inhibition was not observed in osteoblastic cells stimulated with $P$. gingivalis LPS. Interestingly, downregulation of RANKL and increased OPG mRNA expression was already reported in cementoblasts stimulated with $P$. gingivalis LPS [23]. We did not find consistent changes of great magnitude on OPG mRNA expression on fibroblasts and osteoblasts, suggesting that the agonists used to activate TLR and ILIR signaling did not evoke a protective feedback mechanism to maintain bone homeostasis. The relatively minor changes in OPG expression further suggests that the ultimate outcome of bone turnover induced by these agonists might be determined by the changes on the expression of RANKL.

These results illustrate how gene regulation induced by the same agonists may vary depending on cell type, as well as the differential utilization of intracellular signaling pathways in these different cell types. Periodontal ligament fibroblasts have been shown to be relevant for bone formation in periodontal regenerative procedures and also to express RANKL in response to different interleukin-1, lipopolysaccharide, prostaglandin E2 and mechanical stress [24-26] by the activation of mitogenassociated protein kinases (MAPKs). In osteoblasts exposed to the whole bacteria Porphyromonas gingivalis, RANKL mRNA levels were dependent on activation of activator protein 1 (AP-1); but, surprisingly, this activation did not require p38, ERK MAPKs or the phosphoinositol-3-kinase (PI3K) pathway [27]. Recent information indicates that activation of TLR2 or of TLR4 in non-committed osteoclast precursor cells may inhibit RANKL-induced differentiation. This effect is attributed to antagonistic effects of NF-kB activation induced by TLR signaling and NFAT-c1 activation induced by RANKL signaling [28].

NF- $\mathrm{KB}$ and $\mathrm{p} 38 \mathrm{MAPK}$ are involved in the expression of various inflammatory mediators that play a role in the tissue degradation associated with periodontal diseases. We show that both LPSs and IL-1 $\beta$ were able to activate these signaling pathways in periodontal ligament fibroblasts and osteoblastic cells and also modulate the expression of RANKL and, to a lesser extent, of OPG. Interestingly, regulation of these genes at the mRNA level was primarily dependent on p38 MAPK. The varying responses to TLR signaling by different cell types present in the periodontal tissues suggest different roles in the response to bacterial challenge. Understanding the potential role of different cell types and their activation mechanisms can contribute to the development of future strategies in periodontal disease treatment based on interfering with signal transduction.

\section{Competing interests}

The authors declare that they have no competing interests.

Authors' contributions

\begin{tabular}{|l|c|c|c|c|c|}
\hline Authors' contributions & FRML & SGA & MRG & JAC & CR \\
\hline Research concept and design & -- & -- & -- & -- & $\checkmark$ \\
\hline Collection and/or assembly of data & $\checkmark$ & $\checkmark$ & $\checkmark$ & -- & -- \\
\hline Data analysis and interpretation & $\checkmark$ & -- & -- & $\checkmark$ & $\checkmark$ \\
\hline Writing the article & -- & $\checkmark$ & $\checkmark$ & -- & $\checkmark$ \\
\hline Critical revision of the article & -- & -- & -- & $\checkmark$ & $\checkmark$ \\
\hline Final approval of article & -- & -- & $\checkmark$ & -- & $\checkmark$ \\
\hline Statistical analysis & $\checkmark$ & -- & -- & -- & -- \\
\hline
\end{tabular}

Acknowledgement

Financial support provided by FAPESP (Sao Paulo State Research Support Foundation) grants\# 2005/04247-4 and 2005/04351-6 awarded to CRJ.

Publication history

Editor: Deborah A. Lebman, Virginia Commonwealth University, USA.

Received: 07-Apr-2014 Final Revised: 29-Jun-2014

Accepted: 07-Jul-2014 Published: 19-Jul-2014

\section{References}

1. Kawai T, Matsuyama T, Hosokawa Y, Makihira S, Seki M, Karimbux NY, Goncalves RB, Valverde P, Dibart S, Li YP, Miranda LA, Ernst CW, Izumi $\mathrm{Y}$ and Taubman MA. B and T lymphocytes are the primary sources of RANKL in the bone resorptive lesion of periodontal disease. Am J Pathol. 2006; 169:987-98. | Article | PubMed Abstract | PubMed Full Text

2. Kanzaki H, Chiba M, Shimizu Y and Mitani H. Dual regulation of osteoclast differentiation by periodontal ligament cells through RANKL stimulation and OPG inhibition. J Dent Res. 2001; 80:887-91. | Article | PubMed

3. Taubman MA, Valverde $P, \operatorname{Han} X$ and Kawai T. Immune response: the key to bone resorption in periodontal disease. J Periodontol. 2005; 76:203341. | Article | PubMed

4. Rossa C, Ehmann K, Liu M, Patil C and Kirkwood KL. MKK3/6-p38 MAPK signaling is required for IL-1beta and TNF-alpha-induced RANKL expression in bone marrow stromal cells. J Interferon Cytokine Res. 2006; 26:719-29. | Article | PubMed

5. Garlet GP, Martins W, Jr., Ferreira BR, Milanezi CM and Silva JS. Patterns of chemokines and chemokine receptors expression in different forms of human periodontal disease. J Periodontal Res. 2003; 38:210-7. I PubMed

6. Kent LW, Rahemtulla F and Michalek SM. Interleukin (IL)-1 and Porphyromonas gingivalis lipopolysaccharide stimulation of IL-6 production by fibroblasts derived from healthy or periodontally diseased human gingival tissue. J Periodontol. 1999; 70:274-82. | Article I PubMed

7. Qureshi ST, Lariviere L, Leveque G, Clermont S, Moore KJ, Gros P and Malo D. Endotoxin-tolerant mice have mutations in Toll-like receptor 4 (TIr4). J Exp Med. 1999; 189:615-25. | Article | PubMed Abstract | PubMed Full Text

8. Sun Y, Shu R, Li CL and Zhang MZ. Gram-negative periodontal bacteria induce the activation of Toll-like receptors 2 and 4, and cytokine production in human periodontal ligament cells. J Periodontol. 2010; 81:1488-96. | Article | PubMed

9. Darveau RP, Pham TT, Lemley K, Reife RA, Bainbridge BW, Coats 
Leite et al. Immunology Innovation 2014,

http://www.hoajonline.com/journals/pdf/2053-213X-2-1.pdf

doi: $10.7243 / 2053-213 X-2-1$

SR, Howald WN, Way SS and Hajjar AM. Porphyromonas gingivalis lipopolysaccharide contains multiple lipid $A$ species that functionally interact with both toll-like receptors 2 and 4. Infect Immun. 2004; 72:5041-51. | Article | PubMed Abstract | PubMed Full Text

10. Rossa C, Jr., Liu M and Kirkwood KL. A dominant function of p38 mitogen-activated protein kinase signaling in receptor activator of nuclear factor-kappaB ligand expression and osteoclastogenesis induction by Aggregatibacter actinomycetemcomitans and Escherichia coli lipopolysaccharide. J Periodontal Res. 2008; 43:201-11. | Article | PubMed Abstract | PubMed Full Text

11. Tabeta K, Yamazaki K, Akashi S, Miyake K, Kumada H, Umemoto T and Yoshie $\mathrm{H}$. Toll-like receptors confer responsiveness to lipopolysaccharide from Porphyromonas gingivalis in human gingival fibroblasts. Infect Immun. 2000; 68:3731-5. | Article | PubMed Abstract | PubMed Full Text

12. Hatakeyama J, Tamai R, Sugiyama A, Akashi S, Sugawara S and Takada $\mathrm{H}$. Contrasting responses of human gingival and periodontal ligament fibroblasts to bacterial cell-surface components through the CD14/Tolllike receptor system. Oral Microbiol Immunol. 2003; 18:14-23. | PubMed

13. Kikuchi T, Matsuguchi T, Tsuboi N, Mitani A, Tanaka S, Matsuoka M, Yamamoto G, Hishikawa T, Noguchi T and Yoshikai Y. Gene expression of osteoclast differentiation factor is induced by lipopolysaccharide in mouse osteoblasts via Toll-like receptors. J Immunol. 2001; 166:3574-9. | Article | PubMed

14. Takayanagi $\mathrm{H}$. Inflammatory bone destruction and osteoimmunology. $J$ Periodontal Res. 2005; 40:287-93. | Article | PubMed

15. Kwan Tat S, Padrines $M$, Theoleyre S, Heymann D and Fortun $Y$. IL-6, RANKL, TNF-alpha/IL-1: interrelations in bone resorption pathophysiology. Cytokine Growth Factor Rev. 2004; 15:49-60. | Article | PubMed

16. Patil C, Rossa C, Jr. and Kirkwood KL. Actinobacillus actinomycetemcomitans lipopolysaccharide induces interleukin-6 expression through multiple mitogen-activated protein kinase pathways in periodontal ligament fibroblasts. Oral Microbiol Immunol. 2006; 21:392-8. | Article | PubMed

17. Bickel M, Axtelius B, Solioz C and Attstrom R. Cytokine gene expression in chronic periodontitis. J Clin Periodontol. 2001; 28:840-7. I PubMed

18. Zou W and Bar-Shavit Z. Dual modulation of osteoclast differentiation by lipopolysaccharide. J Bone Miner Res. 2002; 17:1211-8. | Article | PubMed

19. Nagasawa T, Kobayashi H, Kiji M, Aramaki M, Mahanonda R, Kojima T, Murakami Y, Saito M, Morotome Y and Ishikawa I. LPS-stimulated human gingival fibroblasts inhibit the differentiation of monocytes into osteoclasts through the production of osteoprotegerin. Clin Exp Immunol. 2002; 130:338-44. | Article | PubMed Abstract | PubMed Full Text

20. Schaeffer HJ and Weber MJ. Mitogen-activated protein kinases: specific messages from ubiquitous messengers. Mol Cell Biol. 1999; 19:2435-44. | Article | PubMed Abstract | PubMed Full Text

21. Wada N, Maeda H, Yoshimine $Y$ and Akamine A. Lipopolysaccharide stimulates expression of osteoprotegerin and receptor activator of NF-kappa B ligand in periodontal ligament fibroblasts through the induction of interleukin-1 beta and tumor necrosis factor-alpha. Bone. 2004; 35:629-35. | Article | PubMed

22. Xiao H, Qian W, Staschke K, Qian Y, Cui G, Deng L, Ehsani M, Wang X, Qian YW, Chen ZJ, Gilmour R, Jiang $Z$ and Li X. Pellino $3 b$ negatively regulates interleukin-1-induced TAK1-dependent NF kappaB activation. J Biol Chem. 2008; 283:14654-64. | Article | PubMed Abstract | PubMed Full Text

23. Nociti FH, Jr., Foster BL, Barros SP, Darveau RP and Somerman MJ. Cementoblast gene expression is regulated by Porphyromonas gingivalis lipopolysaccharide partially via toll-like receptor-4/MD-2. J Dent Res. 2004; 83:602-7. | Article | PubMed

24. Fukushima H, Jimi E, Okamoto F, Motokawa W and Okabe K. IL-1-induced receptor activator of NF-kappa $B$ ligand in human periodontal ligament cells involves ERK-dependent PGE2 production. Bone. 2005; 36:267-75. | Article | PubMed

25. Tiranathanagul $\mathrm{S}$, Yongchaitrakul T, Pattamapun $\mathrm{K}$ and Pavasant $\mathrm{P}$.
Actinobacillus actinomycetemcomitans lipopolysaccharide activates matrix metalloproteinase- 2 and increases receptor activator of nuclear factor-kappaB ligand expression in human periodontal ligament cells. J Periodontol. 2004; 75:1647-54. | Article | PubMed

26. Gottlow J, Nyman S, Karring T and Lindhe J. New attachment formation as the result of controlled tissue regeneration. J Clin Periodontol. 1984 11:494-503. | Article | PubMed

27. Okahashi N, Inaba H, Nakagawa I, Yamamura T, Kuboniwa M, Nakayama $\mathrm{K}$, Hamada $\mathrm{S}$ and Amano A. Porphyromonas gingivalis induces receptor activator of NF-kappaB ligand expression in osteoblasts through the activator protein 1 pathway. Infect Immun. 2004; 72:1706-14. | Article | PubMed Abstract | PubMed Full Text

28. Zhang P, Liu J, Xu Q, Harber G, Feng X, Michalek SM and Katz J. TLR2dependent modulation of osteoclastogenesis by Porphyromonas gingivalis through differential induction of NFATc1 and NF-kappaB. J Biol Chem. 2011; 286:24159-69. | Article | PubMed Abstract | PubMed Full Text

\begin{tabular}{l}
\hline Citation: \\
Leite FRM, Aquino SGd, Guimarães MR, \\
Cirelli JA and Junior CR. RANKL expression is \\
differentially modulated by TLR2 and TLR4 \\
signaling in fibroblasts and osteoblasts. Immunol \\
Innov. 2014; $2: 1$. \\
http://dx.doi.org/10.7243/2053-213X-2-1 \\
\hline
\end{tabular}

